\title{
環境保全を考慮した熱変形対策による高精度旋盤の開発*
}

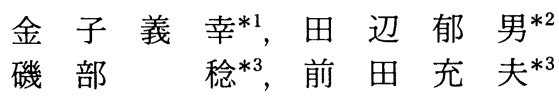

\section{Development of a High Precision Lathe with Countermeasure of Environmental Preservation for Thermal Deformation}

\author{
Yoshiyuki KANEKO*4, Ikuo TANABE, \\ Minoru ISOBE and Michio MAEDA \\ *4 Takamatsu Machinery CO., LTD. \\ 18 Asahigaoka, Matto-shi, Ishikawa, 924-8558 Japan
}

\begin{abstract}
As higher precision machining is required, reducing thermal deformation of a machine tool becomes more important. On the other hand, it is also necessary to save energy for the earth and people. Therefore, we developed a new lathe with environmetal preservation countermeasure. In this report, the new design of lathe structure for reducing thermal deformation has been experimentally investigated. Concepts of these designs are a suitable cost of machine tool, low running cost, low maintenance cost and high precision machining. Three countermeasures which are a design of zerocenter on three directions, a self forced cooling technology and a three-layers structure using thermal insulation unit were proposed for reducing thermal deformation. The developed lathe was evaluated in experiment. It is concluded from the results that thermal deformation of the lathe with these countermeasures was smaller than that of a conventional lathe. In addition, these countermeasures don't use forced cooling system and reduce energy and oil for working its.
\end{abstract}

Key Words: Thermal Deformation, Machine Tool, Lathe, High Precision, Environmental Preservation

\section{1. 楮 百}

最近．工業製品の高精度化，高品位化に伴って，従 来にも增して高精度な加工が要求されてきている。一 方、工業生産活動に対しても環境保全・省エネルギー 化対策が要求されてきており，従来のように高精度加 工を支援するために恒温環境を整えることや，多数の 冷却装置を用いた強制冷却を行なうことが困難になり つつある.

そこで本研究では，環境保全・省エネルギーを考虑 した熱変形抑制対策を施した旋盤を開発し，その効果 を評価する，具体的には，三次元ゼ口芯設計技術(1)， セルフ強制冷却技術 (2)，(3). 断熱ユニットを用いた三 層構造（後述）の3つの対策を施した実機旋盤を試作 し、その熱変形挙動の測定・評価を行い，本対策の効 果について検討を実施した。

\section{2. 桭境保全を考战した筑变形対策}

ここでは，新しい旋盤に施した三次元ゼロ芯設計技 術 (1)，セルフ強制冷却技術 (2)、(3)，断熱ユニットを

* 原稿受付 2004 年 3 月 11 日

*1 正員, 高松機械I業(株) ( 9248558 松任市旭斤r. 18 ）。

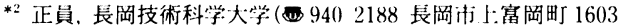
1).

*3 高松機械厂業(株)

E-mail : kaneko(a takamaz.co.jp
用いた三層構造の3つの対策に関して説明する.

$2 \cdot 1$ 三次元ゼロ芯設計技術 三次元ゼロ芯 設計技術 (1) は，機械構造が熱変形することを容認し て，切削点が直交 3 軸各方向の熱変形の基点となるよ うに熱対称な構造とする対策である. 概要を図 1 に示 す．従来から工作機械に使用されているゼロ芯構造 (4) では，主軸台支持部分の影響により，主軸上下方向の 変形については抑制効果がでにくくなっていた。 そこ で本対策では，主軸台とべースの間に断熱の目的でジ ルコニア製の間座を入れることにした，さらに，主軸 台とベースとの空間には，熱放射を防止するためのア ルミ板を設置することにより，主軸から支持部への熱

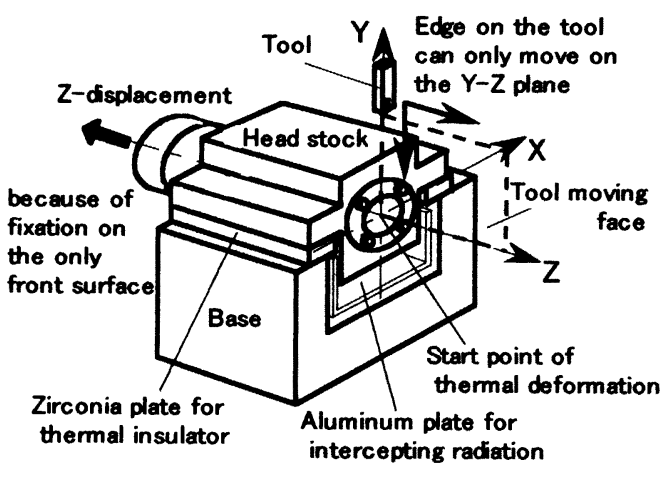

Fig.1 Design of zero-center for three directions 
放射の影響を抑制し．結果として上下方向への熱変形 を抑制可能とした，Z方向については，クイル構造と して主軸台正面のみにボルト締結することにより，熱 変形が主軸台後方へ逃げるようにした．今回の試作旋 盤において，機械のコンパクト化も考虑する必要か ら，X軸方向については構造上完全なゼロ芯構造には できなかった。しかし，本機は刃物の送り（切り込 み）方向を軸方向として、その影響がでにくい構造 にした。

$2 \cdot 2$ セルフ強制冷却技術セルフ強制冷却 技術 (2)，(3) は，撥水性および給水性の良い素材を工作 機械の主軸台正面，背面，上面に貼付し給水させた 後、水の蒸発に伴う気化熱で主軸部分を強制泠却する ものである，概要を図 2 に示す，素材の貼付場所を主 軸台正面，背面，上面としたのは，主軸の回転速度増 加に伴う強制対流が主軸台各部の素材表面部で発生 し、素材の活発な乾燥を促し、結果として大きな熱伝 達率によって強制冷却ができると考えたからである。

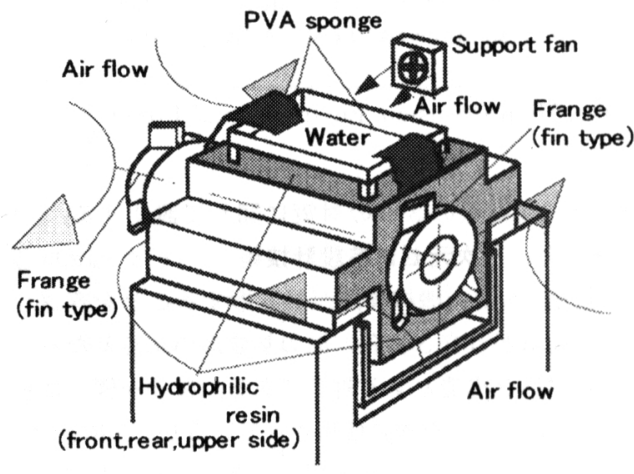

Fig.2 Self forced cooling

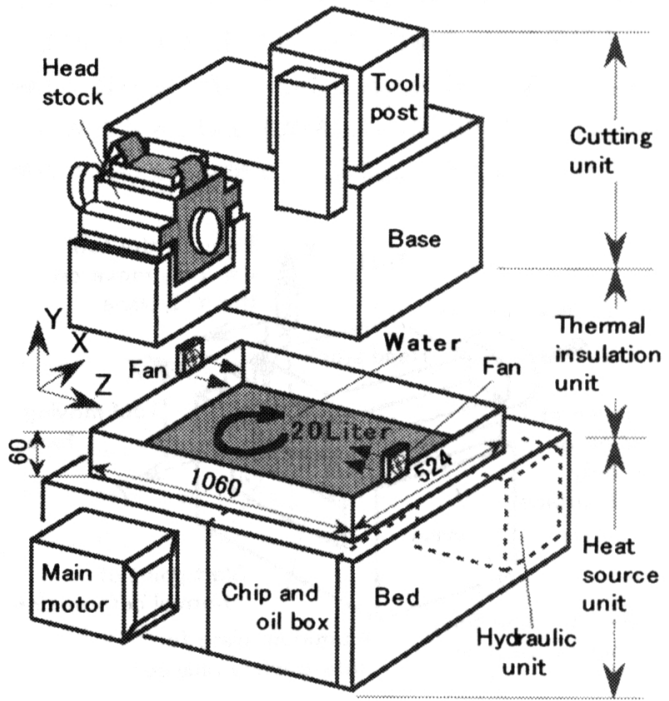

Fig.3 Three-layers structure using thermal insulation unit
今回は，とくに強制対流発生のために、フィン形状を した一体型のフランジを主軸前後両側に取付けした。 予備実験で各面での風速を熱線式センサにより測定し たところ，上面においては正面，背面に比べて風速が 小さかったため, 補助的に出力 16 Wのファンを 1 個設置 して冷却効果を高めることにした。 今回主軸台端面に は，給水素材としてPVAスポンジ，保水素材としてポリ オレフィン系多孔質樹脂を組み合わせたものを貼付し た．主軸台上部に給水タンクを設置してその中にPVAス ポンジを入れて毛細管現象を利用して素材に水を給水 させる．また，フィンは一体型のフランジとしたこと により，回転時のバランスや騒音についても従来型の 機械とほぼ同程度に抑制できた。

以上，前節および本節は著者らのプロトタイプ実験 をもとに実用化のための実機試作である.

$2 \cdot 3$ 断熱ユニットを用いた三層構造旋盤 における一般的な熱源としては。主軸軸受，油圧 チャッキングシリンダ，油圧供給ユニット，切削油ユ ニット，主軸モータ，強電ボックスなどがある，最近 は機械の省スペース化が要求されているため、これら 熱源は機械に緊密に配㯰されることになる。それによ り複雑な熱変形をおこし，ある熱源要素に注目した熱 変形対策をしても，それだけで加工精度が十分に向上 することがむずかしい状況にある、そのため，主軸軸 受、チャッキングシリンダの主軸部熱源は、三次元ゼ ロ芯設計，セルフ強制冷却の技術により対策が可能て あるが，その他の熱源においても対策が必要となる. そこで、これまで点在していた主軸部以外の熱源を可 能な限りベッドの下空間部に配置して，それとベッド 上の加工部分との間に断熱ユニットを設置する構造を 提案した。概要を図 3 に示す。断熱ユニットには，水 が20リットル充填でき，吹出口付きの出力 16 Wのファン 2 台を対角に取付けることにより，カバー内の空気を 平均風速 $7 \mathrm{~m} / \mathrm{s}$ でュニット内へ送った，さらに，断熱層 とベース底部の間に $18 \mathrm{~mm}$ の空間を設けた。これによ り，強制対流による水の擋拌および気化促進を行っ た。これらを集合化させ，水の対流による温度分布の 均一化と水の蒸発による気化熱冷却によって温度上㫒 を抑制し，加工部への熱遮断が可能となると考えた これは，本報で新たに提案する熱変形対策である.

\section{3.対策を施した旋盤の評価}

3・1 製作した旋盤の実験方法前章で述べ たろつの対策を施した旋盤を製作して実験を行った。 図 4 に製作した旋盤を，表 1 に今回の試作旋盤と比較実 験に使用した従来型旋盤の仕様を示す，図5に熟変形の 測定概要を示す，主軸にはテストバーを取付け，刃物台 
には低熱膨張鋳物で作成した治具に渦電流式の変位セ ンサ（分解能1 $\mu \mathrm{m}$ ）を5 個取付け，テストバーのX,Y, Z 各軸方向の主軸一刃物台間の相対変位を 1 時間ごとに 8 時間まで測定した。測定は，X，Y方向は共にテスト バーの先端と根元の各2ヶ所 (150mm間隔) で行い，Z方 向はテストバー取付部端面1ヶ所で行った。.また, 相対 的傾きはテストバーの先端と根元の変位測定值から計 算によって求め, $\alpha$ は軸上, 垂直方向2点（Y1,Y2）。 $\beta$ はZ軸上, 水平方向2点 $(X 1, X 2)$ の変位測定值から算 出した。熱源を含む機械各部（図5中, : 表面部, $\bigcirc$ : 構造内部の計28点）にT型熱電対を取付けて温度 分布測定を行った。実験は室温 $20 \pm 1{ }^{\circ} \mathrm{C}$, 湿度 $40 \%$

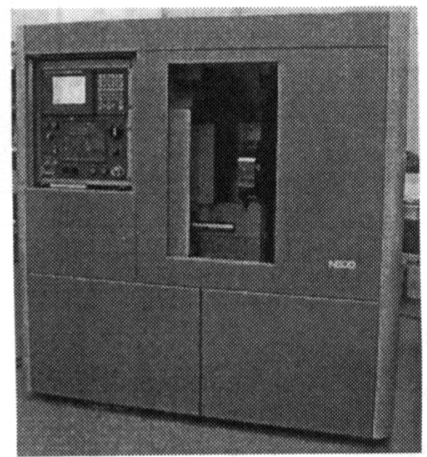

Fig.4 Photograph of the new lathe

Table 1 Specification of the new lathe and the conventional lathe

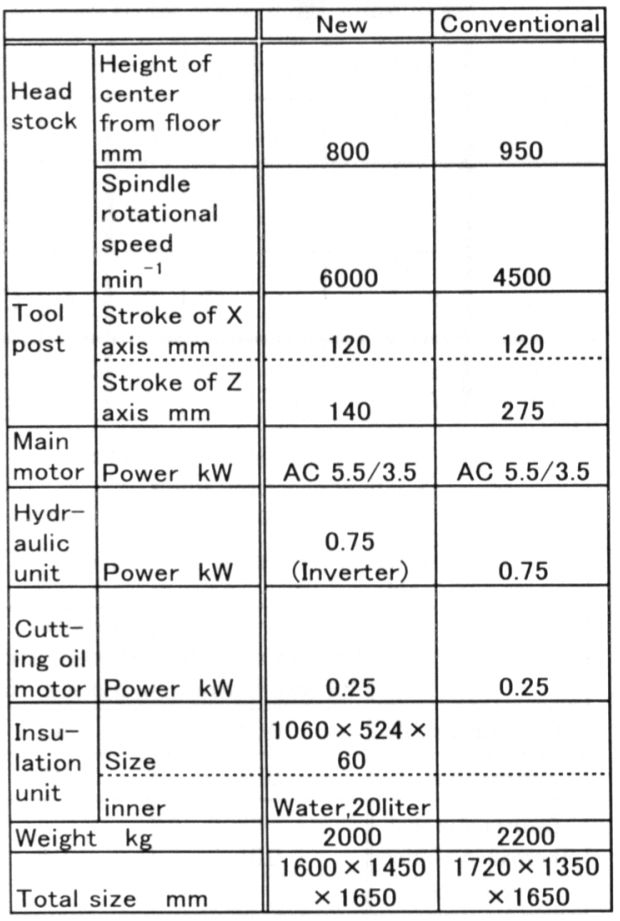

50\%でコントロールされた恒温恒湿室で行った．

3・2 各対策の効果の評価 それぞれの熱変形 抑制対策の影響について評価を行った，対策の比較条 件としては，(1)対策なし（ $N$ : 従来型），試作旋盤にお いて，(2)三次元ゼロ芯設計技術（Z）のみ，(3)三次元ゼ 口芯設計技術 $(Z)+$ + $($ ル 強制冷却技術 $(S)$ の 2 つ を採用. (4)三次元ゼロ芯設計技術 $(Z)+$ 断熱ユニット に水を充填（I）の2つを採用，(5)試作旋盤において 3 つの対策全てを実施の場合（ALL）として効果の確認 を行った。主軸回転速度の条件は図 6 に示すような実 際の加工条件の回転速度变動のプログラムを繰返した 場合（CaseA）と $4500 \mathrm{mi} \mathrm{n}^{-1}$ 一定で回転させた場合

(CaseB) の 2 つとした。図 7 に主軸回転速度変動時 での各条件での主軸ハウジング表面部（図5中a点）の 温度変化を示す。これより，三次元ゼロ芯設計技術を

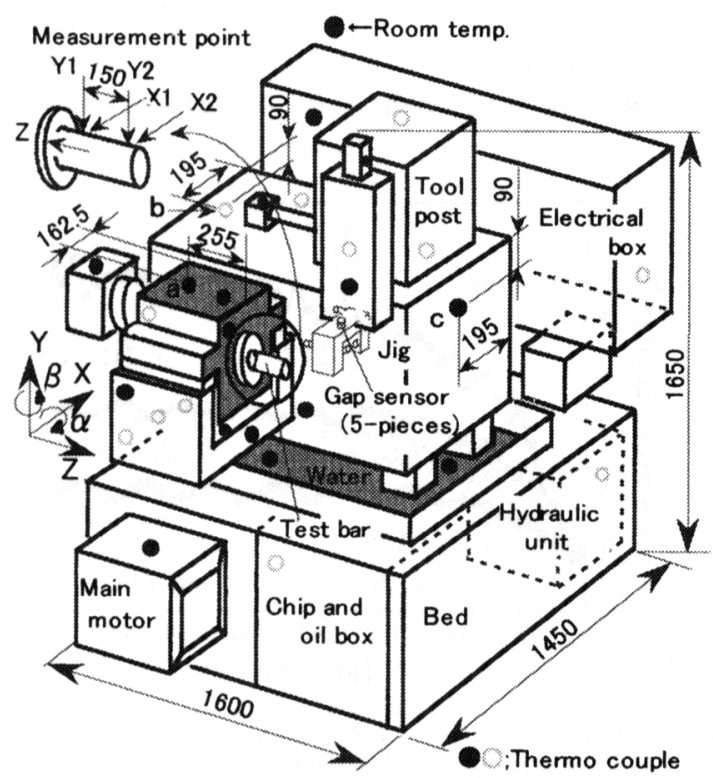

Fig.5 Experimental set-up for measuring thermal deformation

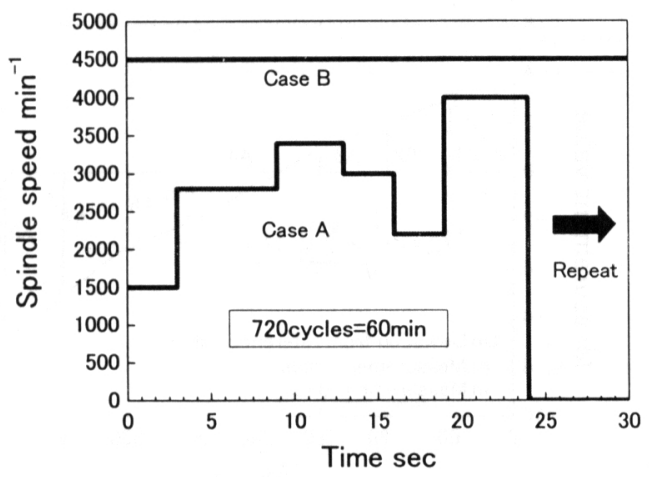

Fig 6 Curve of spindle speed for evaluation 
採用した試作旋盤の場合は従来型に比べて主軸の温度 変化が小さくなっている. 特にセルフ強制冷却技術と 断熱ユニット対策を実施した場合はさらに温度变化が 小さい，これより主軸部の熱影響が効果的に低減でき ていると言える、また，テストバーの各軸方向の相対 変位，相対的傾きの測定結果については，図8に示す ように各測定值を測定前基準よりのずれ量の絶対値の 総和を測定回数で割って偏差としたものを各条件でま とめ、比較しやすくした，その結果を図 9 に示す。こ れより，各対策の実施の違いによる影響を見ると3つ の対策を全て実施した場合が，各軸相対变位，傾きと もに最も小さくなっている，また，主軸を $4500 \mathrm{~min}^{-1} 一$ 定（CaseBの場合）で回転させたときも，3つの対策を 全て実施した場合は，従来機に比べて変形が小さく なっており、主軸回転条件によらず同じような抑制効 果があった。

さらに，断熱ユニットの効果確認のために，従来型 の場合と試作旋盤で断熱ユニットに水を充填した場合

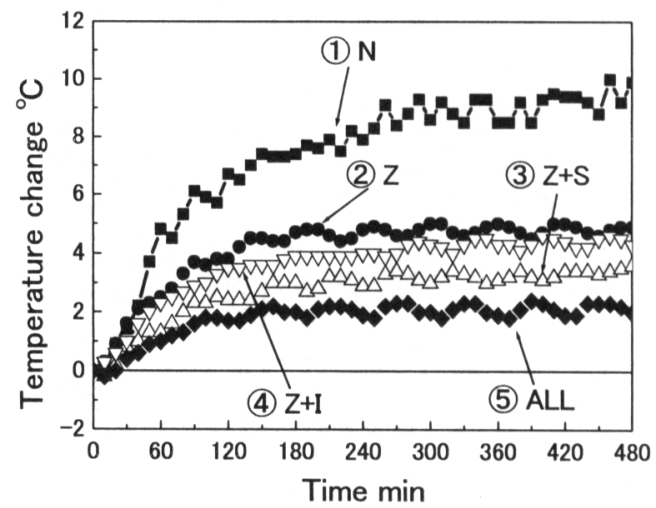

\section{$N$; Conventional $S$;Self forced cooling} $Z$;Zero-center $\quad I$;Thermal insulation unit

Fig.7 Temperature change of headstock at various conditions

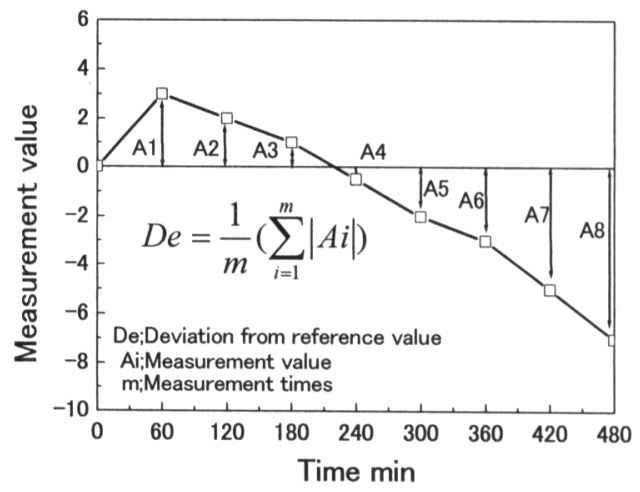

Fig. 8 Calculation method of thermal deformation for evaluation
としない場合の 3 通りについて, ベース左右（図5中， b , c 点）の温度差と傾きについて測定を実施した。傾き はベースの研磨面に水準器を置いて測定した。得られ た結果を表 2 に示す。これより，従来型では最大で約 5 ${ }^{\circ} \mathrm{C}$ 発生したベース左右の温度差が, 断熱ユニット対策 により，その差はほぼゼロになっている，また，試験 終了時のベースの傾きは, 従来型で $0.04 \mathrm{~mm} / \mathrm{m}$ 発生して
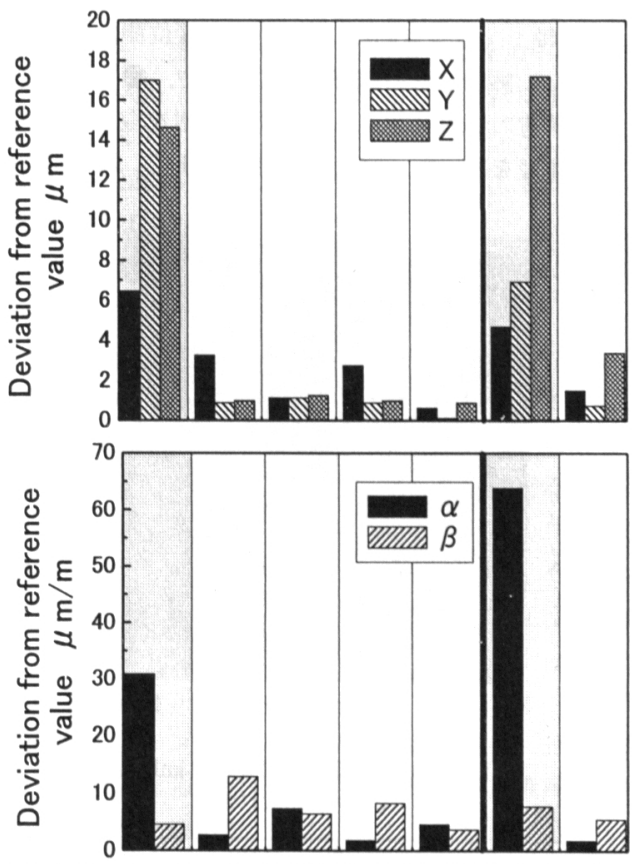

\begin{tabular}{|l|c|c|c|c|c|c|c|}
\hline $\begin{array}{l}\text { Counterme- } \\
\text { asure No. }\end{array}$ & (1) & (2) & (3) & (4) & (5) & (1) & (5) \\
\hline $\begin{array}{l}\text { Zero- } \\
\text { center; } Z\end{array}$ & $\times$ & 0 & 0 & 0 & 0 & $\times$ & 0 \\
\hline $\begin{array}{l}\text { Self- } \\
\text { forced } \\
\text { cooling: } S\end{array}$ & $\times$ & $\times$ & $\bigcirc$ & $\times$ & $\bigcirc$ & $\times$ & 0 \\
\hline $\begin{array}{l}\text { Thermal } \\
\text { insulation } \\
\text { unit: }:\end{array}$ & $\times$ & $\times$ & $\times$ & $\bigcirc$ & $\bigcirc$ & $\times$ & $\bigcirc$ \\
\hline $\begin{array}{l}\text { Spindle } \\
\text { speed }\end{array}$ & $\begin{array}{c}\text { Case } \\
\text { A }\end{array}$ & $\begin{array}{c}\text { Case } \\
\text { A }\end{array}$ & $\begin{array}{c}\text { Case } \\
\text { A }\end{array}$ & $\begin{array}{c}\text { Case } \\
\text { A }\end{array}$ & $\begin{array}{c}\text { Case } \\
\text { A }\end{array}$ & $\begin{array}{c}\text { Case } \\
\text { B }\end{array}$ & $\begin{array}{c}\text { Case } \\
\text { B }\end{array}$ \\
\hline
\end{tabular}

Fig.9 Thermal deformation of the lathe with three countermeasures

Table 2 Effect of the thermal insulation unit

\begin{tabular}{|c||c|c|}
\hline & $\begin{array}{c}\text { Gradient of the bed } \\
\text { for 8hours } \mathrm{mm} / \mathrm{m}\end{array}$ & $\begin{array}{l}\text { Difference } \\
\text { between temp. at } \\
\text { b and at c }{ }^{\circ} \mathrm{C}\end{array}$ \\
\hline \hline Conventional; $N$ & 0.04 & 5.3 \\
\hline Zero-center, $Z$ & 0.02 & 0.9 \\
\hline $\begin{array}{c}\text { Zero-center and } \\
\text { Thermal insulation } \\
\text { unit, } Z H\end{array}$ & 0.01 & 0.5 \\
\hline
\end{tabular}


いるが，断熟ユニット対策によって0.01 mm/mとなっ た.これより，熱源の隔離と断熱ユニットに水を充填 する対策により熱変形抑制効果が高くなっていること がわかる

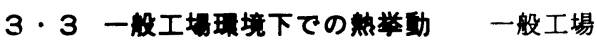

環境下での熱変形挙動を検討するために，恒温室の設

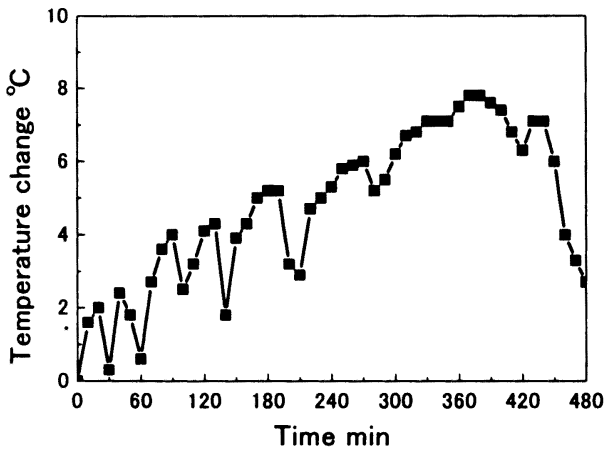

Fig. 10 Room temperature change in a general factory

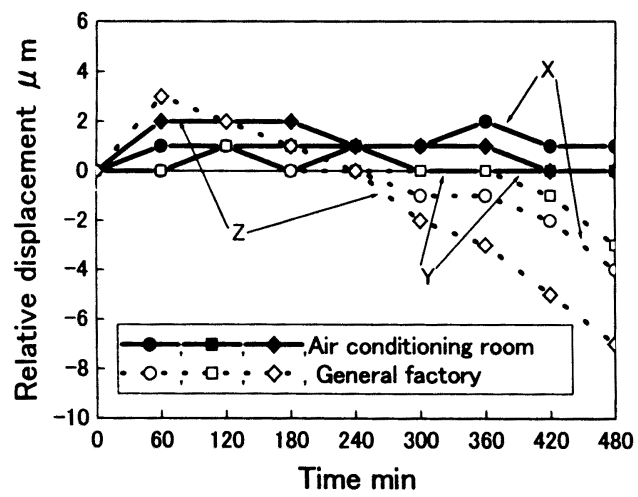

(a) Relative displacement

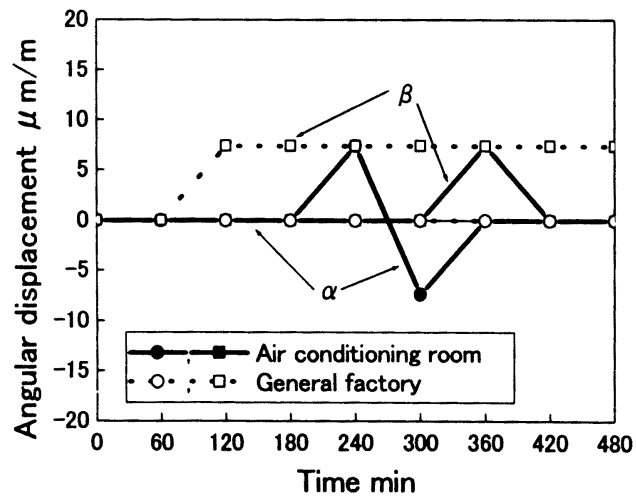

(b) Angular displacement

Fig.11 Experimental results of thermal behavior of a new lathe in a general factory
定を図10に示すように，6時間で $8^{\circ} \mathrm{C}$ 上昇，その後2時間 で $5{ }^{\circ} \mathrm{C}$ 隇少するような環境を恒温室にて模擬的に再現し て実験を行った。これは最も条件が過酷な冬季の一般 工場を想定したものである，途中，值が上下に変動し ているのは，恒温空調設備の設定と追従の時間差が原 因と思われる。図11に得られた実験結果と，比較とし て恒温環境下での結果を併せて示す．これより，相対 変位は，室温変動のゆるやかな前半は，環境の違いに よる差は見られないが，室温が急に下がり始めると変 形が大きくなっており，恒温環境下との違いが大きく 見られる.このことから，一般工場環境下においても 3つの対策は有効であるが，急激な温度变化に対して 熱容量の違いから生じる熱変形の影響を小さくするこ とは難しく，今後他の対策が必要と考えられる。一 方，相対的傾きは小さく安定していた．これは三次元 ゼロ芯構造の影響が大きいものと考えられる.

次に，一般工場環境下での従来型と試作旋盤につい て比較を行った。主軸回転速度を図6中CaseAと同じ条 件とした時の測定結果を図12に示す。これより，試作

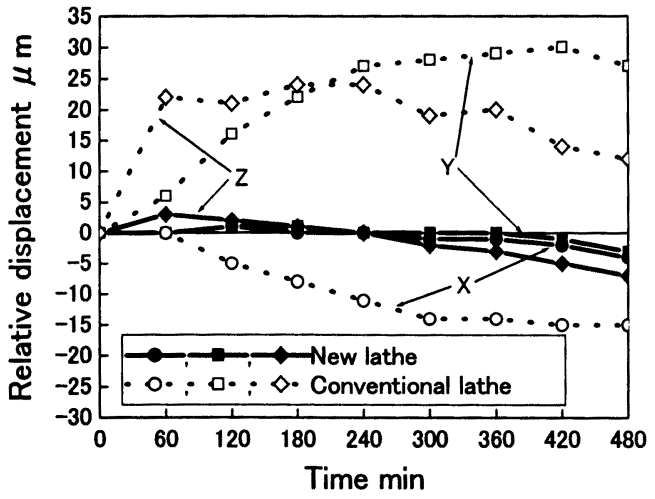

(a) Relative displacement

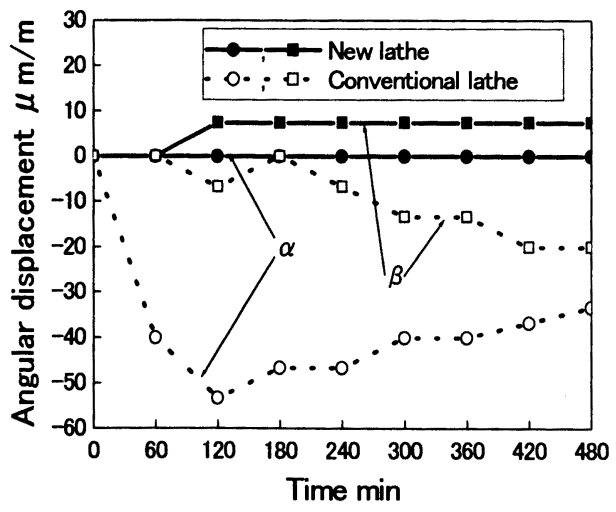

(b) Angular displacement

Fig.12 Experimental results of thermal behavior of two lathes in a general factory 
旋盤は従来型に比べて室温変動による変形の影響が小 さく，本対策は環境の違いによる影響も少なくでき. 有効な対策手法であると考える。これらは，三次元ゼ ロ芯構造とセルフ強制冷却による効果であると考えら れる。

\section{3・4 実切削試験による評価図13，表 3 に} 示すような試験片および切削条件にて8時間の経時変化 切削試験を実施した。恒温恒湿環境下での試験結果を 図14に示す。図中，の部分は，作業者の休憩を 想定し，あえて加工を停止して機械を待機状態のまま にしておいた時間である。また，比較のため従来型旋 盤における試験結果も併せて示す。これより，試作旋 盤は従来型よりも加工径変化が小さくなっている.

また試作旋盤で $3 \cdot 3$ 節と同条件の室温変動環境下 での切削試験結果を図15 に示す。室温変動環境の場 合, 試験開始と同時に加工径が細くなり次第にまた太

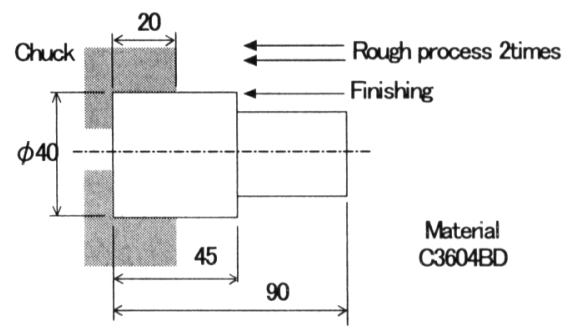

Fig.13 Testpiece

Table 3 Cuting test condition

\begin{tabular}{|c||c|c|}
\hline & Rough processing & Finishing \\
\hline \hline Spindle speed & $2000 \mathrm{~min}^{-1}$ & $2000 \mathrm{~min}^{-1}$ \\
\hline $\begin{array}{c}\text { Cutting } \\
\text { depth(radius) }\end{array}$ & $0.1 \mathrm{~mm}(2 \mathrm{times})$ & $0.05 \mathrm{~mm}$ \\
\hline $\begin{array}{c}\text { Feed speed } \\
\text { Environment }\end{array}$ & $0.1 \mathrm{~mm} / \mathrm{rev}$ & $0.05 \mathrm{~mm} / \mathrm{rev}$ \\
\hline $\begin{array}{c}\text { Chucking } \\
\text { pressure }\end{array}$ & $\mathrm{DRY}$ & $\mathrm{DRY}$ \\
\hline Cycle time & $2.0 \mathrm{MPa}$ & \\
\hline
\end{tabular}

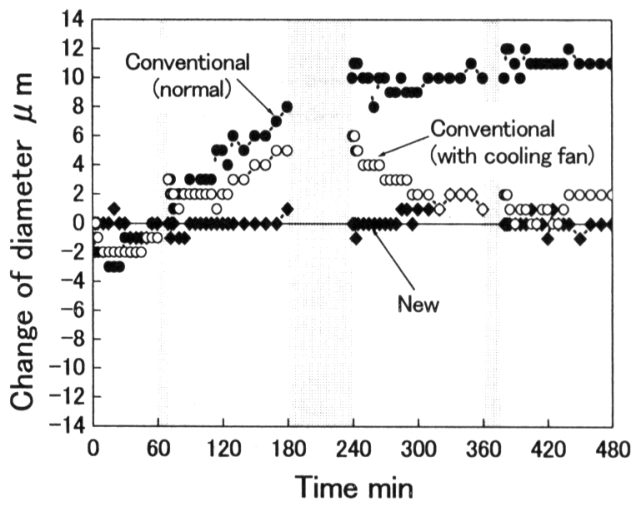

Fig.14 Experimental results of continuance cutting test in an air conditioning room

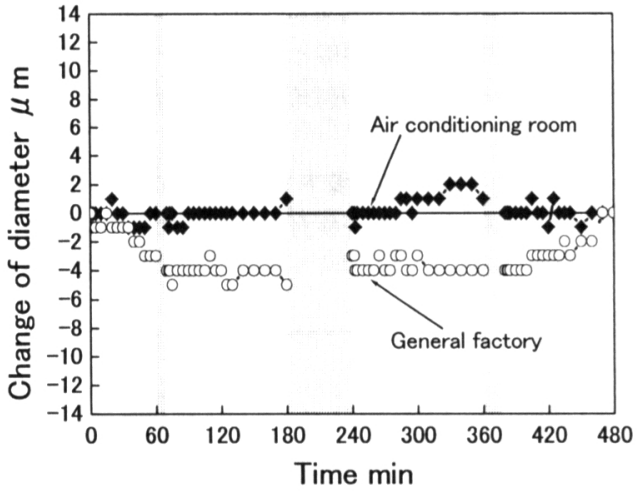

Fig.15 Experimental results of continuance cutting test in a general factory

くなる傾向が見られ，これは，Y方向の相対変位と $\alpha$ 方向の相対的傾きが影響したものであるが，絶対量と して $5 \mu \mathrm{m}$ に抑えられたことは評価できる.

以上のように，三次元ゼロ芯設計技術，セルフ強制 冷却技術, 断熱ユニットを用いた三層構造の 3 つ対 策は, 恒温環境のみならず, 負荷変動や室温变動環境 に対しても，熱変形抑制効果があり，工業的に有効で あると考える，また，消費電力量の比較から，本試作 機は従来機に冷凍機を使用した場合に比べて約40\%削 減できた。

\section{4. 結言}

三次元ゼロ芯設計技術, セルフ強制冷却技術，断 熱ユニットを用いた三層構造の3つの対策には旋盤の 熱変形抑制効果があることが確認できた。これより, 従来の強制冷却装置や恒温環境設備を稼動させるため に必要となる電力や泠却油の使用が隇少し，環境保 全, 省エネルギー化を考慮した熱変形対策が可能であ る.

\section{謝辞}

この研究はNEDO（新エネルギー・産業技術総合開 発機構）との共同研究「エネルギー使用合理化工作機 械等技術開発プロジェクト」として, 助成を受けて行 われたものである。ここに謝意を表す。

\section{参考文献}

（1）田辺, 山中, 水谷, 山田, 機論, 65-639, C, (1999) , 4508-4513 （2）田辺, 松下，中㛢，TRUONG，機論, 66-649，C，(2000)，31503155

（3）田辺，中橋，松下，TRUONG，機論，66-649，C，(2000)，31563161

（4）例元ば，桜庭，機械設計，32-15，(1988)，33-36 